\title{
Fiscal Policy, Factors of Endogenous Growth and Dynamics of Slovenian Exports
}

\author{
France Krizanic $^{1}$, Sabina Hodzic ${ }^{2}$, Borut Vojinovic ${ }^{3}$
}

${ }^{1}$ EIPF, Institute of Economics Ltd.

Einspielerjeva 6, 1000 Ljubljana, Slovenia

E-mail.france.krizanic@eipf.si

${ }^{2}$ University of Rijeka, Faculty of Tourism and Hospitality Management

Primorska 42, Ika, 51410 Opatija, Croatia

E-mail.sabinah@fthm.hr

${ }^{3}$ University of Maribor, Faculty of Tourism and EIPF, Institute of Economics Ltd.

Einspielerjeva 6, 1000 Ljubljana, Slovenia

E-mail.borut.vojinovic@guest.arnes.si

cross $^{\text {ref }}$ http://dx.doi.org/10.5755/j01.ee.32.1.26311

In the modern world of rapidly changing technologies, fiscal policy engagement is also needed to promote and adapt to these changes. In order to achieve economic growth, every country needs to ensure an adequate institutional environment and financial incentives for technological development. These investment incentives operate through tax system directly or indirectly. The aim of the paper is to assess the impact of Slovenia's endogenous economic growth factors on exports in the 2009-2016 period. A panel data analysis was applied to obtain empirical results. The analysis showed that a $1 \%$ real increase in government subsidies to the economy over three subsequent years increases real investment in research and development by $0.45 \%$, and after a two-year period yields a $0.27 \%$ increase in employment of persons with higher education. The latter has a $0.14 \%$ positive impact on the growth of exports after another three-year term. In addition to endogenous factors of economic growth in the Slovenian case, exports are also affected by the dynamics of real world trade, by the dynamics of exchange rates corrected for relative prices, and by the dynamics of wage rates.

Keywords: Fiscal Policy, Exports, Economic Growth, R\&D, Highly Educated Workforce, Slovenia.

\section{Introduction}

Slovenia is at a post-industrial stage of development. Moreover, in the 2009-2016 period the GDP per capita was between 17.7 and 19.6 thousand euros (Republic of Slovenia, Statistical Office, 2020). Prior to joining the euro area, Slovenia maintained competitiveness and steady growth in exports implementing a floating exchange rate. As an economically relatively less developed country, its specialization in labor-intensive production in its trade with the rest of the world (mainly older EU Member States) is well explained by Hecksher-Ohlin's foreign trade theory (Krizanic, 1999). The growth of its industrial production is dependent on export demand and linked to an increase in the share of services in GDP (Syrquin, 1991). The long-term basis of economic growth is exports (Kaldor, 1985).

In 2010, Slovenia was ranked among the strong innovators according to the European Commission typology (European Commission - Innovation Union Scoreboard, 2015). By the EU standards and mostly financed by the EU funds in its most intensive development policy management, the general government expenditure ratio in GDP reached between $50 \%$ and $60 \%$, approaching that of the Scandinavian countries (Kraftova \& Kraft, 2018; Halaskova \& Halaskova, 2017). The relative success of Slovenia's transition to a market economy at the beginning of the 1990s, as well as the success of Slovenia's integration into the EU and the euro area, is reflected by population growth. From 1986 (the last year before the onset of the transition crisis) to 2016, the population in Slovenia increased by $4 \%$ (Republic of Slovenia, Statistical Office, 2012; 2020).

In the scientific literature there is considerable research regarding innovation, technological development, fiscal policy and economic growth, including the research of Hanusch \& Pyka (2007a \& 2007b), Hanusch (2010) and Hanusch, Chakraborty \& Khurana (2017) who have developed an analytical framework titled "comprehensive Neo-Schumpeterian economics" focusing on the impact of innovation on economic development. This approach includes a three-pillar concept, comprising economic, political, and financial conduct. In terms of financial conduct, the most important element is government with fiscal policy as an instrument. Therefore, it is very important to maintain stable and sustainable fiscal policy in order to achieve technological and economic development. Moreover, to finance their development and related research, Slovenian companies invest their own resources, the EU funds, co-financing from customers, benefits of tax releases, etc.

The aim of this paper is to assess the impact of Slovenia's endogenous economic growth factors on exports in the 2009-2016 period. In order to obtain empirical 
results, panel data analysis has been applied. The novelty of this paper lies in the assessment of the impact of endogenous factors of economic growth $(R \& D$ investments and the number of highly qualified employees) on exports, and we also explain what influences the dynamics of mentioned endogenous growth factors.

The structure of the paper and its sections are as follows: Section Theoretical Framework is presented after the Introduction, variables and equations are discussed in the section Data and Methodology, which is followed by the the results of empirical analysis. The last section provides the Conclusion and recommendations for further research.

\section{Theoretical Framework}

The economy at its present stage of development demands state support through financial incentives. It seeks to ensure macroeconomic equilibrium, fair distribution of goods, care for the socially disadvantaged, stimulation of economic and social development, and the organization of the quaternary sector (culture, education, science, health, security) that enables this development. In areas where the private sector is incapable of effective development investment, the public sector must invest directly in the development of new technologies (Evenson \& Westphal, 1995; Mazzucato, 2013) and innovation (Hanusch, Chakraborty \& Khurana 2017). In addition to actively supporting the introduction of technological advancements, heterodox economic policy also included conducting fiscal policy with small fiscal deficits and conducting monetary policy with realistic exchange rates (Rodrik, 1995). In order to conduct an effective technology policy, an institutional framework is needed with a set of mechanisms that identify errors and adapt technology policy accordingly (Rodrik, 2014).

Technological advancement was first analyzed econometrically by Robert Solow (1956) as a constant in the Cobb-Douglas production function. This constant represents the productivity of capital and labor together, or "Total Factor Productivity" (TFP). Following the information revolution since the late 1970s, factors explaining this constant have been incorporated into endogenous growth theory (Romer, 1986, Grossman \& Helpman, 1991). These factors are, in particular, human capital (knowledge) and investment in R\&D. Their engagement leads to technological advancement with increasing returns, learning by doing and a positive impact on the rest of the economy, i.e. positive externalities (Evenson \& Westphal, 1995; Mazzucato, 2013). Technological advances create a temporary monopoly for the innovating company, thus acting as a motivating force for private investment (Bardhan, 1995). Subsequent studies have added other factors to the endogenous growth theory, such as the size of the market and foreign direct investment, as well as the openness of a given national economy (Acemoglu \& Linn, 2004; Snieska \& Volodkiene, 2015). $\mathrm{R} \& \mathrm{D}$ investments and human capital are related to the amount of intangible assets in companies and affect the number and quality - citations - of their patents (Hall et al., 2005, Bistrova et al., 2017). In order to increase R\&D investments, an important determinant are tax incentives for
R\&D within the fiscal policy of a certain country. According to Hutschenreiter (2002) the choice of tax incentives for R\&D depends on degree of innovation, perceived market irregularities in $R \& D$, industrial structure, company's size and nature of tax system within company and respective country. Beside this, to maximize R\&D activities within companies, tax incentives need to be transparent, and easily accessible.

The economy has a certain learning capacity for each form of technology. This capacity depends on past experience in technology development and management. Innovation and entrepreneurship are linked to a changed way of thinking and acting (Stiglitz, 1987). To explain this ability, innovation-based growth theory has introduced the notion of "intellectual capital", which differs from both physical and human capital. This theory also leads to the function of intellectual capital generation, in which innovation activity (patents per employee) depends on investment in R\&D and on the accumulation of human capital (Vila et al., 2015). The ability to learn in a given national economy also depends on its innovation system as part of its institutional framework (Rodriguez-Pose \& Crescenzi, 2011). The innovation system influences the division of skilled labor between production and innovation activities. Depending on the development course, the innovation system changes over time (Alvarez et al., 2016). Analyses have shown that GDP per capita is significantly influenced by a high level of employee education (MihiRamirez et al., 2020).

Various studies, particularly including Grossman \& Helpman (1991), Aghion \& Howitt (1992), Coe \& Helpman (1995) and their reassessment with more modern econometric techniques (Coe et al., 2008) have shown that TFP is influenced by domestic R\&D and the R\&D of trading partners, human capital, business cycle, infrastructure, openness of the national economy (share of exports and imports to GDP), foreign direct investment and direct investment of a given national economy abroad. The importance of human capital on TFP growth was first analyzed by Engelbrecht (1997). The impact of R\&D on TFP is heterogeneous. It is different for large and small countries, but also dependent on institutions. For the latter, it is important how business can be done in a given national economy (licenses, registrations, etc.), the quality of tertiary education, the quality of intellectual property protection and the foundations of the legal system. The effects of current $R \& D$ are constantly transferred to future $R \& D$ as learning (Coe et al., 2008). More recent analyses explain TFP in several equations. Antonelli \& Fasio (2016) first explain intellectual capital (patents per employee) and share of knowledge intensive business services in total employment and use these two variables together with the real level of R\&D expenditure and human capital (share of tertiary education students in the total population) to explain TFP. The structure of the model estimated by Vila et al., (2015) is similar, except that the TFP-weighted distance between regions is included as an explanatory variable to indicate cross-border impacts on economic development. De Melo \& Robinson (1992) cite the results of a study (Nishimizu \& 
Robinson, 1984) according to which TFP in an industry is also influenced by export growth. The impact is linked to economies of scale, technology transfer and incentives to improve competitiveness.

The impact of technology policy is measured by the growth of productivity, output and standard of living (Barber \& White, 1987). In this context, economists inspired by Joseph Schumpeter's work from fiscal policy require funding incentives for investment in $R \& D$ and financing employees for the acquisition of new skills, as well as direct financing for the development of specific technologies and businesses. The synthesis of technology policy into the Keynesian fiscal policy aimed at preventing recession has not been theoretically pursued yet (Mazzucato, 2013; Skare, Tomic, 2015). In the aftermath of the financial and economic crisis, since October 2008, the synthesis between neo-Schumpeterian and Keynesian policies has shown itself at least on a practical level. According to Kraftova \& Kraft (2018), innovation and knowledge-based activity become a major force in economic development, and technology policy becomes an inevitable and important part of a country's fiscal or regional policy.

International trade in the modern world, where competitiveness is largely dependent on knowledge and investment in R\&D, is explained by Krugman's New Trade Theory (1990). According to this theory, a strategic corporate policy, supported by state subsidies, selective development credits and tax credits for funds invested in $\mathrm{R} \& \mathrm{D}$ and in engaging human capital by creating production that would not exist without state aid, generates growing returns and economies of scale. The impact of R\&D or human capital engagement varies by different goods. In this regard, Hirsch (1975) developed a typology of goods between Ricardian goods based on natural resources, Heskscher-Ohlin goods based on a given national economy's abundant production factor (labor or capital) and production cycle goods based on $R \& D$ and the engagement of human capital. With new trade theory, technology policy has also become a key part of trade policy. The openness of a given economy to international trade depends on its export orientation and the country's incentives for an export-led trade policy; otherwise, such an economy becomes a structurally dependent part of the global economy with difficulty financing the imports it needs. In other words, export oriented growth is conditio sine qua non for the stable growth of a modern economy.

\section{Data and Methodology}

In order to obtain empirical results and with the aim of analyzing the impact of factors of Slovenia's endogenous economic growth on exports in the 2009-2016 period, numerous variables were included in panel data analyses. Data on exports, R\&D investments, number of employees with higher education, salaries per employee, ICT funds, orders index and Slovenian inflation were obtained from the SiStat Database (Republic of Slovenia, Statistical Office, 2020). Data on real world trade volume, euro area and US export prices were taken from CPB World Trade Monitor. Data on the euro exchange rate in dollars and on foreign direct investment in Slovenia were obtained in the Monthly Bulletin and Statistical Report published by the Bank of Slovenia. Data on government subsidies to the economy apart from agriculture were collected in the Gov.si Portal, Consolidated Public Finance Balance 1992-2019.

We take into account that exports (E) are influenced by the dynamics of world trade (WT), by the dynamic of relative export prices of Euro group countries and the US, corrected with the Euro exchange rate in dollars (PC), and by the dynamics of wage rates as the prices of Slovenian abundant production factor of labor (W). The dynamics of real $R \& D$ investment are explained in a special equation by market conditions, as perceived by firms in the Orders Index (O) survey, by the need for modernization, as dictated by the digitization of production, as indicated by the dynamics of real volume of information and communication assets in a given industry (ICT) and by the dynamics of real state subsidies to the economy out of agriculture as part of technology policy (S). In our analysis, human capital (HC) represents employees with a college or university degree. The dynamics of their employment are influenced by the given factors: the dynamics of digitization of production (ICT), the dynamics of foreign direct investment (D) and again by the dynamics of real government subsidies to the economy out of agriculture (S). The equations are estimated on natural logarithm differentials, and the coefficients represent elasticity. They show the percentage change in the dependent variable (exports, R\&D investment or number of employees with higher education) caused by $1 \%$ change in the independent variable (world trade volume, foreign direct investment, real government subsidies). Shown schematically:

$$
\begin{aligned}
& \mathrm{d} \ln \mathrm{E}=\mathrm{c}+\mathrm{d} \ln \mathrm{WT}+\mathrm{d} \ln \mathrm{PC}-\mathrm{d} \ln \mathrm{W}+\mathrm{d} \ln \mathrm{HC}+ \\
& \mathrm{d} \ln \mathrm{R} \& \mathrm{D}+\mathrm{f}+\mathrm{u} \\
& \mathrm{d} \ln \mathrm{R} \& \mathrm{D}=\mathrm{c}+\mathrm{d} \ln \mathrm{O}+\mathrm{d} \ln \mathrm{ICT}+\mathrm{d} \ln \mathrm{S}+\mathrm{f}+\mathrm{u} \\
& \mathrm{d} \ln \mathrm{HC}=\mathrm{c}+\mathrm{d} \ln \mathrm{ICT}+\mathrm{d} \ln \mathrm{D}+\mathrm{d} \ln \mathrm{S}+\mathrm{f}+\mathrm{u}
\end{aligned}
$$

Investments in R\&D, ICT assets and government subsidies to the economy are deflated and thus represent real values. The same holds for world trade volume. The equations are estimated on the annual data variables for 2009 to 2016 in the panel of the 51 branches of the Slovenian economy (NACE Rev 2, two-digit numerical code). Series were tested for Unit Root (Dickey \& Fuller, 1979), and the hypothesis that the series has a single root was rejected. The test, of course, showed that there is no first-order unit root on the panel data in the form of first differences. In the same way, panel series were also tested for the effect of cointegration (Pedroni, 2000; 2001). Only series were included in the equations where we rejected the cointegration hypothesis. The time lag of the influence of the dependent variable on the independent variable was not estimated automatically, but gradually by including individual variables in the equation and checking the economic significance of the results. Eviews 10 software was used in the analysis. 


\section{Empirical Results}

Our analysis provided interesting results. Based on observed results from the tables $(1,2,3)$ the dynamics of exports of goods and services are explained by almost $61 \%$, the dynamics of real investments in R\&D by almost $36 \%$ and the dynamics of employees with higher education by $80 \%$. Durbin-Watson statistics are between 2.2 and 2.3, which indicate that there is no first order autocorrelation. The first column of the tables $(1,2,3)$ sets out the determinants that, according to economic theory, affect exports, $R \& D$ and human capital. The second column shows the variables that affect exports, real investment in R\&D and the employment of people with higher education. The parentheses on the right of the variables' names in this column indicate the time lag (how many years of change in the independent variable is needed to produce the change in the dependent variable). The last column of the tables presents the coefficients showing the influence of an independent variable on the dependent variable. In brackets below the coefficients are the t-statistic values. For all the independent variables involved, these are much larger than 1 . The impact is therefore statistically significant.

Based on observed results, we found that with $1 \%$ change (growth or decline) in world trade volume, Slovenian exports increase (decrease) by $0.81 \%$, a $1 \%$ change in price competitiveness yields a $0.07 \%$ change, while $1 \%$ increase (decrease) in wage rates causes a decrease (increase) of exports by $0.44 \%$. Changes in the global market and price competitiveness have a one-year delayed affect on exports, and a change in wage rates has a two-year delay. With a $1 \%$ increase (decrease) in the number of employees with higher education, exports are shown to increase (decrease) by $0.14 \%$, while an increase (decrease) of real investment in R\&D of $1 \%$ leads to an increase (decrease) in exports of only $0.003 \%$. For both crucial variables of endogenous growth, the impact on exports is delayed for three years. The results show that the Slovenian economy is strongly responsive to the global economy and is less affected by the real euro exchange rate. The specialization of the Slovenian economy in HecksherOhlin goods shows a high negative elasticity of exports on labor costs. On the other hand, during the analyzed period, the Slovenian economy was building competitiveness through additional engagement of human capital (employment of people with higher education), while the fluctuation of the real volume of investments in R\&D only slightly affected the Slovenian export of goods and services. The longer time lag of this impact is consistent with the time lag estimates in analyzing the effect of the real volume of R\&D investment on TFP (Rouvinen, 2002; Coe et al., 2008).

\footnotetext{
1 Aggregate series

2 Development grants, in a certain percentage of the value of an enterprise's investment in R\&D or other development expenditures, are practically the only allowed state aid in the EU (Jovanovic, 2005).
}

Table 1

Factors Affecting the Dynamics of Slovenian Exports

\begin{tabular}{|c|c|c|}
\hline \multirow{2}{*}{$\begin{array}{l}\text { Differences of } \\
\text { logarithms }\end{array}$} & Independent variable (lag in years) & $\begin{array}{c}\text { Coefficient } \\
\text { (t-statics) }\end{array}$ \\
\hline & Constant & $\begin{array}{r}0.027 \\
(2.0) \\
\end{array}$ \\
\hline World trade ${ }^{1}$ & Real world trade volume (-1) & $\begin{array}{l}0.813 \\
(2.0)\end{array}$ \\
\hline $\begin{array}{l}\text { Price } \\
\text { competitiveness } \\
\text { of the euro area }^{1}\end{array}$ & $\begin{array}{c}\text { US export prices } \\
\text { Euro area export prices*exchange rate } \\
\text { euro in dollars } \\
(-1)\end{array}$ & $\begin{array}{c}0.066 \\
(2.1)\end{array}$ \\
\hline Labor costs & Slovenian nominal wage rates $(-2)$ & $\begin{array}{c}-0.442 \\
(-2.6)\end{array}$ \\
\hline Human capital & $\begin{array}{c}\text { Employed with a college or } \\
\text { university degree }(-3)\end{array}$ & $\begin{array}{l}0.141 \\
(2.1) \\
\end{array}$ \\
\hline $\mathrm{R} \& \mathrm{D}$ & $\frac{\text { R\&D investments }}{\text { Slovenian inflation rate }}(-3)$ & $\begin{array}{l}0.003 \\
(1.6)\end{array}$ \\
\hline $\mathrm{R}^{2}$ & 60.8 & \\
\hline DW & 2.3 & \\
\hline & $\begin{array}{l}51 \text { industries in the period from } \\
2009 \text { to } 2016\end{array}$ & \\
\hline
\end{tabular}

Source: Authors' estimates

The results from Table 2 show the rapid and strong influence of the dynamics of the business cycle (survey about orders on the market) on the decision by the Slovenian economy to increase or decrease the real volume of investments in R\&D. The elasticity is around 1 and the impact already arrives in the current year. Slovenia's investments in R\&D are clearly linked to the import of technological progress. A change in the real value of ICT assets by $1 \%$ after two years brings a $1.3 \%$ higher real level of investment in R\&D. Development policy or fiscal incentives to the economy (excluding agricultural subsidies) $)^{2}$ have an impact already in the current year, and the impact continues for the next two years. With a $1 \%$ increase in the real volume of subsidies, the real level of investment in $\mathrm{R} \& \mathrm{D}$ increases by $0.43 \%$ overall.

Table 2

Factors Affecting the Dynamics of Slovenia's real Investment in $R \& D$

\begin{tabular}{|c|c|c|}
\hline \multirow{2}{*}{$\begin{array}{l}\text { Differences } \\
\text { of logarithms }\end{array}$} & Independent variable (lag in years) & $\begin{array}{c}\text { Coefficient } \\
\text { (t-statics) }\end{array}$ \\
\hline & Constant & $\begin{array}{c}0.284 \\
(7.5)\end{array}$ \\
\hline $\begin{array}{l}\text { The state of } \\
\text { the business } \\
\text { cycle }^{1}\end{array}$ & Orders according to the survey & $\begin{array}{l}1.042 \\
(7.3)\end{array}$ \\
\hline Digitization & $\frac{\text { ICTassets }}{\text { Slovenian inflation rate }}(-2)$ & $\begin{array}{l}1.326 \\
(4.5)\end{array}$ \\
\hline Subsidies $^{1}$ & $\frac{\text { Government subsidies }}{\text { Slovenian inflation rate }}(0$ to -2$)$ & $\begin{array}{c}0.433 \\
(7.3) \\
\end{array}$ \\
\hline $\mathrm{R}^{2}$ & 35.7 & \\
\hline DW & 2.3 & \\
\hline & $\begin{array}{l}51 \text { industries in the period from } \\
2009 \text { to } 2016\end{array}$ & \\
\hline
\end{tabular}

Source: Authors' estimates 
The dynamics of human capital or employment of persons with higher education (Table 3 ) is to some extent related to digitization. An increase in the real level of ICT assets by $1 \%$ after one year yields a $0.03 \%$ increase in the number of employees with higher education. Human capital engagement is strongly influenced by foreign direct investment. An increase in its real level after a three-year adjustment period has an impact of a $0.55 \%$ increase in the number of employees with higher education. Finally, Table 3 shows that the impact of development policy (real volume of government subsidies to the economy, excluding agricultural subsidies) on the employment of persons with higher education is slower (time lag is 2 years here) and weaker (elasticity is $0.27 \%$ ) than the impact of the same policy measures on the real level of investment in R\&D.

Table 3

Factors Affecting the Employment Dynamics of People with Higher Education

\begin{tabular}{|c|c|c|}
\hline $\begin{array}{l}\text { Differences of } \\
\text { logarithms }\end{array}$ & $\begin{array}{l}\text { Independent variable } \\
\text { (lag in years) }\end{array}$ & $\begin{array}{l}\text { Coefficient } \\
\text { (t statics) }\end{array}$ \\
\hline & Constant & $\begin{array}{l}0.094 \\
(16.4)\end{array}$ \\
\hline Digitization & $\frac{\text { ICT assets }}{\text { Slovenian inflation rate }}(-1)$ & $\begin{array}{c}0.025 \\
(1.7)\end{array}$ \\
\hline $\begin{array}{l}\text { Foreign direct } \\
\text { investment }^{1}\end{array}$ & $\frac{\text { Foreign direct investment }}{\text { Slovenian inflation rate }}(-3)$ & $\begin{array}{l}0.547 \\
(7.3)\end{array}$ \\
\hline Subsidies $^{1}$ & $\frac{\text { Government subsidies }}{\text { Slovenian inflation rate }}(-2)$ & $\begin{array}{l}0.269 \\
(6.5)\end{array}$ \\
\hline $\mathrm{R}^{2}$ & 79.9 & \\
\hline DW & 2.2 & \\
\hline & $\begin{array}{l}51 \text { industries in the period from } \\
2009 \text { to } 2016\end{array}$ & \\
\hline
\end{tabular}

Source: Authors' estimates

A simulation of all three equations shows that a $1 \%$ increase in subsidies to the economy (except for agriculture) after an adjustment period produces a $0.04 \%$ increase in Slovenian exports of goods and services, and it holds in the negative scenario as well. Reducing government subsidies reduces exports of goods and services below the level it could reach. The low percentage of impact is due to differences in scale. Between 2010 and 2011, Slovenian exports of goods and services on average accounted for 23.4 billion euros, and subsidies to the economy (excluding agricultural) on average accounted for 0.3 billion euros (Republic of Slovenia, Statistical Office, 2020, Gov.si Portal, 2020). This means that 1 million euros of increased state subsidies to the economy after the adjustment period leads to the 3.1 million euros higher exports of goods and services.

\section{Conclusion}

Technology policy comprises all economic policy instruments that allow enterprises, consumers and the government to access the latest technologies as cheaply as possible. Such policy enhances invention, innovation, the level of investment in R\&D and encourages the diffusion of innovation, new technologies and new best practices.

Fiscal policy can, through government subsidies, affect the employment of people with higher education (human capital) or the real level of investment in R\&D - two of the most important factors in the endogenous economic growth. In this manner, fiscal policy can also act as a measure against recession. Fiscal expansion can, thus, be used by the state to stimulate the economy to introduce technological development. For a modern economy, the only way to effectively introduce new technologies, products and business approaches is to be completely open to the world. By engaging in economic integration, such as the EU, even a small national economy like Slovenia gains a sufficiently large market, and, at the same time, it gets the opportunity to make technological advancements by importing equipment and implementing best business practices. In today's context, the acceleration of digitization has a particularly strong effect in this area.

Following the results of empirical analysis, this paper reveals a significantly wider knowledge gap, both theoretical and empirical. We found that exports in a small, open economy like Slovenia are affected by factors of endogenous economic growth (especially investment in R\&D and human capital) as well as by other factors related to foreign trade (demand on the world market, exchange rates and price changes, and prices of production factors particularly wage rates for relatively less developed national economies).

The analysis of Slovenian case shows that fiscal policy (subsidies to the economy) has a faster and stronger impact on the investment in R\&D than on the employment of human capital (people with higher education), but the growth of highly educated employee engagement is significantly more effective in stimulating export growth than the investment in R\&D. Obviously, a relatively less developed nation's economy increases its technological effort according to employee knowledge rather than R\&D investments. These forms of technological effort are connected to improving the organization of business processes in various aspects. This does not mean, however, that investments in R\&D are not important in promoting export growth. During the period of crisis, the Slovenian economy reduced its investments in fixed assets, particularly investments in equipment, but, on the other hand, it increased its investments in intangible fixed assets: intellectual property products (Republic of Slovenia, Statistical Office, 2020). In this context, we can expect positive influence from investments in $R \& D$ resulting in an increase of Slovenian export of goods and services in the future. A recommendation for further research would be to investigate the relationship between fiscal policy and technological development in other EU countries, and to determine the impact of specific group of determinants of economic growth.

\section{Acknowledgements}

The authors acknowledge the financial support from the Slovenian Research Agency (funding No. P5-

0287-0541-18). 
France Krizanic, Sabina Hodzic, Borut Vojinovic. Fiscal Policy, Factors of Endogenous Growth and Dynamics...

\section{References}

Acemoglu, D., \& Linn, J. (2004) Market Size in Innovation: Theory and Evidence from the Pharmaceutical Industry. Quarterly Journal of Economics, 119(3), p. 1049-1090. https://doi.org/10.1162/0033553041502144

Aghion, P., \& Howitt, P. (1992) A Model of Growth Through Creative Destruction. Econometrica, 60(2), p. 331-3351. https://doi.org/10.2307/2951599

Alvarez, I., Di Caprio, D., \& Santos-Arteaga, F. J. (2016) Technological Assimilation and Divergence in Times of Crisis. Technological and Economic Development of Economy, 22(2), p. 254-273. https://doi.org/10.3846/2029491 $\underline{3.2015 .1033663}$

Antonelli, C., \& Fassio, C. (2016) Globalization and the Knowledge-Driven Economy. Economic Development Quarterly, 30(1), p. 3-14. https://doi.org/10.1177/0891242415617239

Banka Slovenije, Monthly Bulletin, March 2017.

Banka Slovenije, Statistical reports, Direct Investment, 2019.

Barber, J., White, G. (1987) Current Policy Practise and Problems a UK Perspective, in Dasgupta P. and Stoneman P, Economic Policy and Technological Performance, Cambridge University Press, Cambridge, New York, New Rochelle, Melbourne, Sydney, 24-50. https://doi.org/10.1017/CBO9780511559938.004

Barthan, P. (1995) The Contributions of Endogenous Growth Theory on The Analysis of Development Problems: An Assessment, in Handbook of development Economics, ed. Behrman, J. and Srinivasan T.N., Volume 3A, North Holland, Amsterdam, Lausanne, New York, Oxford, Shannon, Tokyo, 2983-2998. https://doi.org/10.1016/S1573$\underline{4471(95) 30023-6}$

Bensel, T., \& Elmslie, B. T. (1992). Rethinking International trade Theory: A Methodological Apraisal. Weltwirtschaftliches Archiv, 128(2), 249-265. https://doi.org/10.1007/BF02707546

Bistrova, J., Lace, N., Tamosiuniene, R., \& Kozlovskis, K. (2017). Does Firm's Higher Inovation Potential Lead to its Superior Financial Performance? Case of CEE Countries. Technological and Economic Development of Economy, 23(2), 375-391. https://doi.org/10.3846/20294913.2016.1266411

Coe, D. T., Helpman, E. (1995). International R\&D Spillovers. European Economic Review, 39(5), 859-887. https://doi.org/10.1016/0014-2921(94)00100-E

Coe, D. T., Helpman, E., \& Hoffmaister, A. W. (2008). International R\&D Spillovers and Institutions, IMF Working paper. Asia and pacific and European Departments, WP/08/104. https://doi.org/10.5089/9781451869651.001

CPB World Trade Monitor, Merchandise world trade, fixed base 2010=100, 20 September 2019.

De Melo, J., \& Robinson, S. (1992). Productivity and Externalities: Models of Export led Growth. Journal of International Trade and Economic Development, 1(1), 41-68. https://doi.org/10.1080/09638199200000004

Dickey, D. A., \& Fuller, W. A. (1979). Distribution of the Estimators for Autoregressive Time Series with Unit Root. Journal of the American Statistical Association, 74(366), 427-431. https://doi.org/10.1080/01621459.1979.10482531

Engelbrecht, H. J. (1997) International R\&D Spillovers Human capital, and Productivity in OECD Countries: An Empirical Investigation. European Economic Review, 41(8), 1479-1488. https://doi.org/10.1016/S0014-2921(96)00046-3

European Commission, European Innovation Scoreboard, interactive tool, 2015.

Evenson, R. E., \& Westphal, L. E. (1995). Technological Change and Technology Strategy in Handbook of development Economics, ed. Behrman, J. and Srinivasan T.N., Volume 3A, North Holland, Amsterdam, Lausanne, New York, Oxford, Shannon, Tokyo, 2209-2298. https://doi.org/10.1016/S1573-4471(05)80009-9

Gov.si Portal, Consolidated Public Finance Balance 1992 -2019.

Greiner, A. (2016). Human capital formation and public debt: growth and welfare effects of three different deficit policies. Journal of Economic Policy Reform, 19(4), 369-385. https://doi.org/10.1080/17487870.2015.1128834

Grossman, G., \& Helpman, E. (1991) Innovation and Growth in the Global Economy, Cambridge, MA: MIT Press, pp. 359.

Halaskova, M., \& Halaskova, R. (2017). Public Expenditures in Areas of Public Sector: Analysis and Evaluation in EU Countries. Scientific Paper of the University of Pardubice, Series D. 24 (39-1/2017), 39-50.

Hall, B. H., Jaffe, A., \& Trajtenberg, M. (2005). Market Value and patent Citations. The RAND Journal of Economics, $36(1), 16-38$. 
Hanusch, H. (2010). Fighting the Crisis: Public Sector Governance in a Comprehensive Neo-Schumpeterian System. Homo Oeconomicus, 27(1/2), 89-104.

Hanusch, H., \& Pyka, A. (2007a). The Principles of Neo-Schumpeterian Economics. Cambridge Journal of Economics, 31(2), 275-89. https://doi.org/10.1093/cje/bel018

Hanusch, H., \& Pyka, A. (2007b). Applying a Comprehensive Neo-Schumpeterian Approach to Europe and its Lisbon Agenda, in 50 Years of EU Dynamics, Integration-Financial Markets and Innovations, eds. Tilly, R., Welfens, P \& Heise, M., Berlin, Heidelberg, and New York: Springer, 275-300. https://doi.org/10.1007/978-3-540-74055-1_19

Hanusch, H., Chakraborty, L. S., \& Khurana. S. (2017). Fiscal Policy, Economic Growth and Innovation: An Empirical Analysis of G-20 Countries, Levy Economics Institute Working Paper No. 883. https://doi.org/10.2139/ssrn.2924801

Hirsh, S. (1975). The Product Cycle Model of International Trade: A Multi-Country Cross-Section Analysis. Oxford Bulletin of Economics and Statistics, 37(4), 305-317. https://doi.org/10.1111/j.1468-0084.1975.mp37004004.x

Jovanovic, M. N. (2005). The Economics of European Integration, Limits and Prospects, Edward Elgar Publishing, Inc., Northampton - Massachusetts, 918.

Kaldor, N. (1985). Economics Without Equilibrium, New York: M.E., Sharpe, Inc., pp. 79.

Kraftova I., \& Kraft J., (2018). The Relationship Between Pro-Innovation Factors and the Performance of the European Union Member states and their Regions. Inzinerine Ekonomika - Engineering Economics, 29(4), 424-433. https://doi.org/10.5755/j01.ee.29.4.19703

Krizanic, F. (1999). Orientation of Slovenian foreign trade by areas, sectors and production factors - On the sources of Slovenian competitiveness on the world market, Economic Trends, 307, Ljubljana 29-51.

Krizanic, F., \& Vojinovic, B. (2019). Heterodox Policy for the Development of Small Open Economy - Historical Analysis, in Bezpartochnyi M. et. al., Organizational-economic mechanism of management of economic entities, Higher School of Social and Economic in Przeworsk, Poland, 323-338.

Krugman, P. R. (1990). Rethinking International Trade, Cambridge: MIT Press, pp. 282. https://doi.org/10.7551/mitpress/ $\underline{5933.001 .0001}$

Mazzucato, M. (2013). The Entrepreneurial State, Debunking Public vs. Private Sector Myths, Anthem Press, London New York - Delhi, 201.

Mihi-Ramirez, A., Melchor-Ferrer, E., \& Sobieraj, J. (2020). Integration and productivity of Labor Factor in Europe. Perspective from Nationality and the Attainment Level. Inzinerine Ekonomika - Engineering Economics, 31 (1), 1825. https://doi.org/10.5755/j01.ee.31.1.24477

Nishimizu, M., \& Robinson, S. (1992). Trade Policies and Productivity Change in Semi-Industrialized Countries. Journal of Development Economics, 16(1/2), 177-206. https://doi.org/10.1016/0304-3878(84)90106-8

Pedroni, P. (2000). Fully Modified OLS for Heterogeneous Cointegrated panels, Recent Developments in the Econometrics of Panel Data, 1, 424-461.

Pedroni, P. (2001). Purchasing Power parity Tests in Cointegrating Panels. Review of Economics and Statistics, 83(4), 727731. https://doi.org/10.1162/003465301753237803

Republic of Slovenia, Statistical Office, SiStat Database, Detailed Statistics and Tables, Ljubljana, 2020.

Republic of Slovenia, Statistical Office, Statistical Yearbook, pp. 589, Ljubljana 2012.

Republic of Slovenia, Portal GOV.SI, Consolidated Public Finance Balance 1992-2019.

Rodriguez-Pose, A., Crescenzi, R. (2011). Research and Development, spillovers, innovation systems, and the Genesis of Regional Growth in Europe. Regional Studies, 42(1), 51-67. https://doi.org/10.1080/00343400701654186

Rodrik, D. (1995). Trade and Industrial Policy Reform, in Handbook of development Economics, ed. Behrman, J. and Srinivasan T.N., Volume 3A, North Holland, Amsterdam, Lausanne, New York, Oxford, Shannon, Tokyo, p. 29252982. https://doi.org/10.1016/S1573-4471(95)30022-8

Rodrik, D. (2014). Green Industrial Policy. Oxford Review of Economic Policy, 30(3), 469-491. https://doi.org/10.1093/ oxrep/gru025

Romer, P. (1986). Increasing returns and long-run growth. Journal of Political economy, 94(5), 1002-1037. https://doi.org/ $\underline{10.1086 / 261420}$

Rouvinen, P. (2002). R\&D-productivity dynamics: causality, lags, and dry holes. Journal of Applied Economics, 5(1), 123156. https://doi.org/10.1080/15140326.2002.12040573 
Snieska, V., \& Valodkiene, G. (2015). Impact of Innovations upon Economic Growth During Recession. Technological and Economic Development of Economy, 21(4), 626-642. https://doi.org/10.3846/20294913.2015.1055615

Solow, R. M. (1956). A Contribution to the Theory of Economic Growth, Qurterly Journal of Economics, The MIT Press, 70(1), 65-94. https://doi.org/10.2307/1884513

Stiglitz, J. E. (1987). Learning to Learn, in Dasgupta P. and Stoneman P, Economic Policy and Technological Performance, Cambridge University Press, Cambridge, New York, New Rochelle, Melbourne, Sydney, 125-153.

Syrquin, M. (1991). Patterns of Structural Change in Handbook of development Economics, ed. Chenery, H. and Srinivasan T. N., Volume 1, North Holland, Amsterdam, New York, Oxford, Tokyo, 203-273. https://doi.org/10.1016/S15734471(88)01010-1

Skare, M., \& Tomic D. (2015). Business Cycle - Growth Nexus: A Review. Technological and Economic Development of Economy, 21(3), 519-538. https://doi.org/10.3846/20294913.2015.1048837

Vila, L. E., Cabrer, B., \& Pavia, J. M. (2015). On the Relationship between Knowledge Creation and Economic Performance. Technological and Economic Development of Economy, 21(4), 539-556. https://doi.org/10.3846/202 94913.2013.876687

\section{Authors' biographies}

France Krizanic: $\mathrm{PhD}$ in Economics; received $\mathrm{PhD}$ on the Faculty of Economics in Zagreb (1997). He is scientific councilor at EIPF, Economic Institute Ltd. in Ljubljana. His research interests are: External Exchange and Capital Flow, Economic Growth, Energy and Ecology. He served as Chairman of the Council of Experts of the Insurance Supervision Agency of the Republic of Slovenia (2000 - 2005), Director of EIPF Economic Institute Ltd. (2001 - 2008), the Minister of Finance in the Government of the Republic of Slovenia (2008-2012), and the Member of the National Assembly of the Republic of Slovenia (2014 - 2015).

Sabina Hodzić: PhD in Economics, Associate Professor and Head of the Department of Public Finance at the Faculty of Tourism and Hospitality Management, University of Rijeka (Croatia). Her main fields of research are Public Finance, International Taxation issues and Local and Regional Government. She lectures on public finance and international taxation and is the author of several papers published in scientific journals. As a part of professional training, she stayed at Vienna University of Economics and Business (2018), University of New South Wales, Australia (2018), and University of Economics, Slovakia (2016).

Borut Vojinović: PhD in Economics, Associate Professor, University of Maribor, Faculty of Tourism and EIPF, Institute of Economics Ltd., Ljubljana. His research interests are: Economics, Macroeconomics, International Economics and Tourism. He is an author of several research papers published in different scientific journals and listed on https://orcid.org/0000-0002-6417-6166. He is also a member of Editorial Team at Lex localis, Journal of Local Self Government, an JCR listed journal. During his professional training he lectured at the several international universities.

The article has been reviewed.

Received in May 2020; accepted in February 2021.

This article is an Open Access article distributed under the terms and conditions of the Creative Commons Attribution 4.0 (CC BY 4.0) License (http://creativecommons.org/licenses/by/4.0/). 